\title{
Kondisi Tutupan Karang di Desa Ratatotok Timur Kabupaten Minahasa Tenggara
}

\author{
Dion A. Ginoga a*, Deidy Y. Katili a, Adelfia Papu a \\ aJurusan Biologi, FMIPA, Unsrat, Manado
}

\begin{tabular}{|c|c|}
\hline KATA KUNCI & A B S TR A K \\
\hline $\begin{array}{l}\text { Tutupan karang } \\
\text { Ratatotok Timur } \\
\text { Line Intercept Transect }\end{array}$ & $\begin{array}{l}\text { Telah dilakukan penelitian untuk menentukan kondisi tutupan karang di } \\
\text { desa Ratatotok Timur, Kabupaten Minahasa Tenggara. Penelitian ini } \\
\text { dilakukan untuk memberikan informasi tentang tutupan karang di } \\
\text { Ratatotok Timur sehingga dapat dijadikan acuan dalam usaha } \\
\text { pengelolaan, pemeliharaan dan pelestarian terumbu karang di Daerah } \\
\text { tersebut. Sampling dilakukan menggunakan metode LIT (Line Intercept } \\
\text { Transect) pada kedalaman } 5 \text { meter dan } 10 \text { meter. Hasil penelitian } \\
\text { menunjukkan bahwa kondisi tutupan karang secara umum tergolong } \\
\text { kategori tutupan sedang. }\end{array}$ \\
\hline KEYWORDS & A B S TR A C T \\
\hline $\begin{array}{l}\text { coral covering } \\
\text { East Ratatotok } \\
\text { Line Intercept Transect }\end{array}$ & $\begin{array}{l}\text { A research was carried out to determine the condition of Coral covering in } \\
\text { East Ratatotok Village, District of Southeast Minahasa. This research was } \\
\text { carried out to give information about coral covering in East Ratatotok and } \\
\text { was expected to be a reference in managing, maintaining, and preserving } \\
\text { coral reefs in the area. Sampling was carried out using LIT (Line Intercept } \\
\text { Transect) method in } 5 \text { meter and } 10 \text { meter depths. The result shows that } \\
\text { the coral covering was classified as moderate coral reef covering. }\end{array}$ \\
\hline
\end{tabular}

TERSEDIA ONLINE

01 Februari 2016

\section{Pendahuluan}

Sulawesi Utara merupakan salah satu daerah yang termasuk dalam wilayah Coral Triangle. Selain itu, tingkat diversitas terumbu karang yang ada di daerah ini juga cukup tinggi. Salah satu daerah di Sulawesi Utara yang memiliki cakupan ekosistem terumbu karang yang cukup luas yaitu daerah Ratatotok Timur.

Pantai Ratatotok ini merupakan daerah yang masih sangat minim informasi penelitian. Kawasan ini termasuk baru dalam perlakuan konservasi. Mengingat pertumbuhan karang yang umumnya lambat, maka wajar jika life coral diawali dengan acropora. Berbeda dengan beberapa daerah penelitian lain di Sulawesi, seperti Pulau Kapoposang, yang telah lama ditetapkan oleh pemerintah (Kementerian Kelautan dan perikanan divisi pengelolaan pesisir dan pulau-pulau kecil), sehingga lifeform yang umum lebih tinggi dari dead coral (Papu, 2010).
Menurut BKSDA (1997) ekosistem terumbu karang merupakan salah satu ekosistem yang rapuh sehingga tergolong ke dalam ekosistem yang laju kepunahannya relatif cepat bila mendapat gangguan. Terumbu karang merupakan suatu komunitas biologi yang tumbuh pada dasar batu gamping yang resisten terhadap gelombang.

Terumbu karang sebagai suatu ekosistem merupakan kelompok organisme yang hidup di dasar perairan dan berupa bentuk batuan gamping $\left(\mathrm{CaCO}_{3}\right)$ yang cukup kuat menahan gelombang laut. Terumbu karang terbentuk melalui proses yang lama dan kompleks, dimulai dari terbentuknya endapan masif kalsium karbonat yang dihasilkan oleh hewan karang filum Cnidaria, kelas anthozoa, ordo Sclerectinia dengan sedikit tambahan alga berkapur dengan organisme lain yang juga menghasilkan kalsium karbonat yang disebut terumbu (Mellawati, 2012). 


\begin{abstract}
Menurut Nybakken (1992), terdapat dua kelompok karang yang berbeda, yang satu dinamakan ahermatipik dan yang lainnya hermatipik. Karang ahermatipik ditemukan di seluruh dunia sedangkan karang hermatipik hanya ditemukan di wilayah tropis dan karang bentuk inilah yang membentuk terumbu.

Penyusun utama ekosistem ini adalah hewan karang dari golongan Coelenterata, yang merupakan struktur di dasar laut berupa deposit kalsium karbonat di laut. Pertumbuhan karang dipengaruhi oleh factor abiotik dan biotik. Faktor abiotik dapat berupa intensitas cahaya, lama penyinaran, suhu, nutrisi, dan sedimentasi. karang dapat beradaptasi dalam perairan yang miskin nutrient namun tidak dapat beradaptasi terhadap kenaikan jumlah nutrient yang terjadi secara mendadak. Faktor biotik meliputi predasi, kompetisi, agresi karang lain, dan lainnya.

Penelitian ini bertujuan untuk mendata kondisi tutupan karang di Desa Ratatotok Timur, Minahasa Tenggara.
\end{abstract}

\section{Bahan dan Metode}

Penelitian ini dilakukan pada bulan JuniAgustus 2015 di Desa Ratatotok Timur Kabupaten Minahasa tenggara. Analisis data dilakukan di lokasi pengamatan. Alat dan bahan yang digunakan antara lain alat selam (Scuba Diving), salinometer, pHmeter, meteran, kamera underwater, termometer, dan alat tulis.

Penelitian dilakukan di pulau-pulau yang terdapat di desa Ratatotok Timur. Lokasi penelitian dibagi menjadi tiga stasiun, yaitu:

(I) Merupakan daerah tujuan bagi orang-orang yang ingin berwisata pantai. Wisata pantai yang biasanya dilakukan seperti snorkeling, berjemur, dan diving.

(II) Merupakan daerah yang menjadi tempat penangkapan ikan oleh para nelayan karena berada tepat di tengah-tengah deretan Pulau Putus-putus. Nelayan yang beraktifitas di lokasi ini merupakan nelayan dengan kapal-kapal kecil.
(III) Merupakan tempat berlabuhnya kapal-kapal besar. Selain itu, lokasi ini juga merupakan lokasi memancing bagi para nelayan.

Terumbu karang didata dengan pengambilan data tutupan karang, dengan menggunakan transek garis sepanjang $50 \mathrm{~m}$. Data dicatat dan diukur dengan ketelitian hingga satuan $\mathrm{cm}$. adapun kategori yang diamati adalah $\mathrm{LC}=$ Life Coral, $\mathrm{DC}=$ Death Coral, $\mathrm{A}=$ Algae, $\mathrm{OT}=$ Others, dan $\mathrm{ABT}=$ Abiotic.

Analisis data menggunakan rumus sebagai berikut (English et. al., 1994):

$$
P c=\frac{L i}{L_{\text {Total }}} \times 100 \%
$$

dengan : $P c=$ persen tutupan; $L i=$ panjang tutupan lifeform; dan Ltotal = panjang transek

Penentuan kondisi terumbu karang dilakukan berdasarkan kriteria baku kerusakan terumbu karang berdasarkan Keputusan Menteri LH No.4 Tahun 2001 pada Tabel 1.

Tabel 1. Kriteria baku kerusakan Terumbu Karang Berdasarkan Keputusan Menteri Lingkungan Hidup No. 4 Tahun 2001.

\begin{tabular}{lc}
\hline KONDISI & $\begin{array}{c}\text { PENUTUPAN KARANG } \\
\text { HIDUP (\%) }\end{array}$ \\
\hline Buruk & $0-24,9$ \\
Sedang & $25-49,9$ \\
Baik & $50-74,9$ \\
Baik Sekali & $75-100$ \\
\hline
\end{tabular}

Kondisi terumbu karang dikelompokkan menurut stasiun dan disajikan dalam bentuk tabel serta akan dianalisis secara deskriptif.

\section{Hasil dan Pembahasan}

Secara umum, tutupan karang di Ratatotok Timur didominasi oleh rubble (52,74\%) (Tabel 2) yang merupakan patahan-patahan karang.

Tabel 2. Persentase tutupan terumbu karang secara umum

\begin{tabular}{|c|c|c|c|c|c|c|c|}
\hline \multirow{2}{*}{ Stasiun } & \multirow{2}{*}{ Kedalaman } & \multicolumn{5}{|c|}{ Lifeform (\%) } & \multirow{2}{*}{ Kondisi Karang } \\
\hline & & LC & OT & A & $\mathrm{ABT}$ & DC & \\
\hline I & 5 dan10 meter & 56.86 & 4.42 & 0 & 37.15 & 1.57 & Baik \\
\hline II & 5 dan10 meter & 29.09 & 3.02 & 0 & 49.73 & 18.16 & Sedang \\
\hline III & 5 dan10 meter & 18.2 & 0.29 & 0 & 71.35 & 10.16 & Buruk \\
\hline \multicolumn{2}{|c|}{ Persentase rata-rata } & 34.72 & 2.58 & 0.00 & 52.7433 & 9.96 & \\
\hline
\end{tabular}

Menurut Lalamentik (2013), permasalahan perusakan karang disebabkan oleh beberapa masalah seperti bom ikan, racun, jala, predator
(Acanthaster plancii) dan pemutihan karang yang jelas terjadi pada tahun 1997, 2000 dan 2010. Coral bleaching (pemutihan karang) yang terjadi beberapa kali merupakan faktor utama penyebab 
kerusakan terumbu dan dapat menjelaskan bagaimana tutupan karang didominasi oleh rubble. Bentuk patahan karang (rubble) yang tersebar umumnya berasal dari karang acropora mati. Kerusakan juga sangat dipengaruhi oleh adanya aktivitas manusia di sekitar, seperti pelepasan jangkar oleh kapal nelayan akan memberikan dampak yang buruk bagi pertumbuhan karang tersebut. Jangkar kapal dapat mengakibatkan patahnya cabang-cabang karang yang memberi sumbangan rubble.
Tutupan karang selanjutnya adalah acropora. Sebagian besar penyusun karang hidup di daerah ini tergolong dalam jenis karang acropora (Acropora Branching dan Acropora Submassive) yang secara alamiah merupakan karang perintis. Meskipun sangat rentan rusak karena bentuknya yang bercabang dan mudah patah, pertumbuhan karang ini juga termasuk paling cepat (English et.al., 1994).

Tabel 3. Persentase Tutupan Terumbu Karang di Ratatotok Timur, Minahasa Tenggara Stasiun 1.

\begin{tabular}{llll}
\hline Kedalaman & Lifeform & Panjang Tutupan & \% Tutupan (PC) \\
\hline 5 Meter & CB & 0,25 & 0,5 \\
& ACB & 30,51 & 61,02 \\
& ACT & 2,55 & 5,1 \\
& CF & 1,81 & 3,62 \\
& SC & 1 & 2 \\
& CM & 0,21 & 0,42 \\
& DC & 1,32 & 2,64 \\
& S & 3 & 6 \\
& R & 9,35 & 18,7 \\
\hline Total Tutupan Karang Hidup & & & 70,66 \\
\hline 10 Meter & ACB & 20,51 & 41,02 \\
& SC & 1,1 & 49,6 \\
& CF & 0,2 & 2,2 \\
& CM & 0,82 & 0,4 \\
& R & 23 & 2,04 \\
& SP & 1,02 & 0,5 \\
& DC & 0,25 & 1,64 \\
& ZO & 1,09 & 2,6 \\
\hline
\end{tabular}

Secara umum kondisi tutupan karang berdasarkan Keputusan Menteri LH No. 4 Tahun 2001 di stasiun I tergolong dalam kategori baik dengan nilai tutupan karang hidup 56,85\% (Tabel 2). Apabila dibandingkan penelitian yang dilakukan oleh Rembet et.al. (2011) kondisi tutupan karang di stasiun ini sudah mengalami peningkatan. Pada tahun 2011, kondisi tutupan karang hidup di lokasi ini adalah 54,90\% yang artinya pada tahun 2015 sudah meningkat sebesar 2,04\%. Apabila dilihat dari tabulasi data yang telah disajikan (Tabel 3) menunjukkan bahwa karang jenis acropa merupakan penyusun terbesar ekosistem terumbu karang yang ada di daerah tersebut. Manuputty (1990) mengungkapkan bahwa jenis-jenis karang batu dari marga acropora mempunyai polip sangat kecil dan sulit untuk membersihkan dirinya dari partikel-partikel yang melekat, sehingga jenis ini membutuhkan arus dan ombak yang cukup kuat. Lokasi pengamatan yang berpapasan langsung dengan laut lepas ini memungkian acropora mendapatkan kuat arus yang dibutuhkan untuk tumbuh dengan baik.

Meskipun pada stasiun ini persentase tutupan tertinggi adalah tutupan karang hidup tetapi persentase patahan karang (rubble) juga tergolong tinggi. Hal ini menunjukkan bahwa pada lokasi I dampak aktifitas manusia mulai terasa. Fungsi ekowisata pantai dari lokasi ini seperti diving dan snorkeling juga menjadi salah satu penyebab tingginya patahan karang di daerah ini. Menurut Brown (2004), lokasi menyelam popular akan mengundang masuknya para penyelam yang nantinya akan menjadi perusak ekosistem terumbu karang.

Kondisi tutupan karang hidup di stasiun ini tergolong baik namun perlu dijaga, mengingat pada lokasi ini terdapat bekas-bekas penggunaan metode panangkapan ikan yang merusak terumbu karang seperti bom. Hal itu dapat dilihat dari jumlah patahan karang (rubble) yang cukup tinggi yaitu $18,7 \%$. Nilai ini hampir $1 / 4$ dari keseluruhan data yang ada. 
Pengamatan pada stasiun II menunjukkan bahwa daerah ini didominasi oleh kategori abiotik (ABT) berupa patahan karang atau rubble 49,73\%. Jumlah penutupan karang hidup (LC) $29,09 \%$. Kategori selanjutnya adalah Other Fauna 3,02\% dan kategori lainnya adalah Death Coral (DC) $18,16 \%$.
Pada lokasi ini teramati persentase tutupan karang hidup sebesar 34,38\% pada kedalaman 5 meter dan sebesar $23,8 \%$ pada kedalaman 10 meter. Persentase tutupan karang hidup lebih rendah pada kedua titik pengambilan data dibandingkan dengan persentase Rubble dan Death Coral (Tabel 4).

Tabel 4. Persentase Tutupan Terumbu Karang di Ratatotok Timur, Minahasa Tenggara Stasiun 2

\begin{tabular}{|c|c|c|c|}
\hline Kedalaman & Lifeform & Panjang Tutupan & \% Tutupan (PC) \\
\hline \multirow[t]{9}{*}{5 Meter } & ACS & 13,93 & 27,86 \\
\hline & CE & 1,46 & 2,92 \\
\hline & $\mathrm{R}$ & 16,81 & 33,62 \\
\hline & $\mathrm{DC}$ & 13,19 & 26,38 \\
\hline & ACB & 0,98 & 1,96 \\
\hline & OT & 1,23 & 2,46 \\
\hline & $\mathrm{CM}$ & 0,82 & 1,46 \\
\hline & $\mathrm{SP}$ & 1,33 & 2,66 \\
\hline & DCA & 0,25 & 0,5 \\
\hline \multicolumn{3}{|c|}{ Total Tutupan Karang Hidup } & 34,38 \\
\hline \multirow[t]{10}{*}{10 Meter } & ACS & 8,99 & 17,98 \\
\hline & $\mathrm{DC}$ & 4,51 & 9,02 \\
\hline & CME & 0,95 & 1,9 \\
\hline & ACE & 0,8 & 1,6 \\
\hline & $\mathrm{R}$ & 32,92 & 65,84 \\
\hline & ACB & 0,77 & 1,54 \\
\hline & DCA & 0,21 & 0,42 \\
\hline & $\mathrm{CB}$ & 0,26 & 0,52 \\
\hline & $\mathrm{CF}$ & 0,13 & 0,26 \\
\hline & $\mathrm{SC}$ & 0,46 & 0,92 \\
\hline \multicolumn{3}{|c|}{ Total Tutupan Karang Hidup } & 23,8 \\
\hline
\end{tabular}

Menurut Keputusan Mentri LH No.4 Tahun 2001 kondisi tutupan karang pada lokasi ini tergolong kategori sedang dengan nilai tutupan karang hidup sebesar 29,09\% (tabel 2). Hal ini terkait dengan fungsi dari lokasi ini. Berdasarkan kegunaan stasiun II, sangat terlihat jelas bekasbekas penggunaan metode yang salah dalam penangkapan ikan yang dilakukan oleh masyarakat sekitar. Hal ini ditunjukkan oleh tingginya nilai tutupan rubble yaitu $33,62 \%$ pada kedalaman 5 meter dan $65,84 \%$ pada kedalaman 10 meter.

Selain tingginya nilai tutupan rubble salah satu hal yang perlu diperhatikan adalah terdapatnya death coral. Death coral yang diamati disini adalah akibat coral bleaching (pemutihan karang). Selain penggunaan bom, penggunaan senyawa kimia dalam penangkapan ikan menjadi salah satu factor terjadinya kematian pada karang di lokasi ini (bleaching). Menurut Erftemeijer et. al., (2012), jenis karang acropora akan mengalami penarikan polip, peningkatan produksi mucus, dan pemutihan apabila terjadi peningkatan sedimentasi dan turbiditas di air. Peningkatan turbiditas ini terjadi apabila terdapat senyawa-senyawa kimia di dalam air laut.

Apabila dilihat dari persentase rubble pada stasiun ini yang cukup besar dapat diketahui bahwa nelayan yang beraktifitas memancing disini sebagian besar menggunakan bom. Menurut Pontoh (2011), bahan peledak seberat $0,5 \mathrm{~kg}$ dapat menyebabkan kerusakan dalam radius $3 \mathrm{~km}$ hancur sama sekali. Ujung-ujung karang menjadi patah, sedangkan pada radius 10 meter ikan-ikan langsung mati. Aktifitas penangkapan ikan dengan menggunakan bom tersebut akan sangat berdampak pada eksistensi karang yang ada disekitarnya, terutama pada karang jenis acropora yang tergolong rentan mengalami patahan.

Stasiun III didominasi oleh tutupan abiotic (ABT) $71,35 \%$. Tutupan untuk kategori karang hidup (LC) $18,2 \%$. Selain itu terdapat pula tutupan oleh kategori Other Fauna (OT) 0,29\% dan kategori death coral (DC) 10,16\%. Persentase tutupan karang hidup adalah sebesar $28,9 \%$ pada kedalaman 5 meter dan sebesar $7,5 \%$ pada kedalaman 10 meter. Tutupan karang hidup pada lokasi ini 
merupakan yang terendah dibandingkan dengan lokasi pengamatan yang lain (Tabel 5).

Tabel 5. Persentase Tutupan Terumbu Karang di Ratatotok Timur, Minahasa Tenggara Stasiun 3

\begin{tabular}{llll}
\hline Kedalaman & Lifeform & Panjang Tutupan & \% Tutupan (PC) \\
\hline 5 Meter & $\mathrm{R}$ & 29,71 & 59,42 \\
& $\mathrm{CM}$ & 1,15 & 2,3 \\
& ACS & 12,82 & 25,64 \\
& DC & 5,55 & 11,1 \\
& $\mathrm{CE}$ & 0,45 & 0,9 \\
& $\mathrm{CB}$ & 0,03 & 0,06 \\
& $\mathrm{SP}$ & 0,29 & 0,58 \\
\hline Total Tutupan Karang Hidup & & & 28,9 \\
\hline 10 Meter & $\mathrm{CF}$ & 1,63 & 3,26 \\
& $\mathrm{R}$ & 41,64 & 83,28 \\
& $\mathrm{ACS}$ & 0,71 & 1,42 \\
& $\mathrm{DC}$ & 4,61 & 9,22 \\
& $\mathrm{CE}$ & 0,79 & 1,58 \\
& ACB & 0,35 & 0,7 \\
& $\mathrm{CM}$ & 0,13 & 0,26 \\
& $\mathrm{CB}$ & 0,14 & 0,28 \\
\hline Total Tutupan Karang Hidup & & & 7,5
\end{tabular}

Total Tutupan Karang Hidup

7,5

Berdasarkan keputusan Mentri LH No.4 Tahun 2001 kondisi tutupan karang hidup pada stasiun 3 tergolong dalam kategori buruk dengan nilai tutupan karang hidup 18,2\% (tabel 2). Stasiun III merupakan lokasi yang digunakan masyarakat sekitar sebagai pelabuhan kapal-kapal besar dan juga sebagai lokasi nelayan memancing ikan. Pada stasiun ini kategori yang mendominasi adalah rubble 59,42\% pada kedalaman 5 meter dan $83,28 \%$ pada kedalaman 10 meter. Hal ini diakibatkan oleh fungsi dari lokasi pengamatan ini sendiri.

Pada stasiun ini, kategori Abiotik berupa patahan karang (rubble) memiliki persentase tutupan paling tinggi yaitu $71,35 \%$. Hal ini menunjukkan bahwa pada daerah ini sudah terkena dampak yang besar dari aktifitas manusia. Apabila dikaitkan dengan fungsi dari lokasi ini yang merupakan pelabuhan kapal-kapal besar dan juga tempat pemancingan para nelayan, rusaknya ekosistem karang pada daerah ini sangat sulit untuk dihindari.

\section{Kesimpulan}

Tutupan karang di Desa Ratatotok Timur Kabupaten Minahasa Tenggara secara umum berada pada kondisi sedang (35,75\%). Disarankan perlunya recovery terumbu karang di daerah ini karena kondisinya belum seperti yang diharapkan sesuai dengan baku lingkungan menurut Keputusan Menteri LH No. 4 Tahun 2001 yaitu lebih dari 50\% tutupan karang hidup.

\section{Daftar Pustaka}

[BKSDA] Badan Konservasi Sumber Daya Alam, 1997. Laporan Pelaksanaan Badan Konservasi Sumber Daya Alam (BKSDA) Rencana Pengelolaan Taman Wisata Alam Kepulauan Kapoposang Kabupaten Pangkajene dan Kepulauan Propinsi Sulawesi Selatan. Direktorat Kerjasama Jendral Pembangunan Daerah dengan Direktorat Jenderal Perlindungan Hutan dan Pelestarian Alam. Hal 1-30.

Brown, R., Gentry-Gruber, J., Hardesty, J., Meyer, M., Roth, M., Thompson, J., and Weir, W. 2004. The Coral Reef Teacher's Guide. Key West: Florida.

Erftemeijer, P. L.A., Rieg| B., Hoeksema, B.W., and Todd, P.A. 2012. Environmental impacts of dredging and other sediment disturbances on corals: a review. Marine Pollution Bulletin, 64:1737-1765.

English, S., Wilkinson, C., Baker,V,. 1994. Survey Manual For Tropical Marine Resources. ASEAN - Australia Marine Science Project Living Coastal Resources. Australiaan institute of Marine Science. Townsville. 390p.

Keputusan Menteri Lingkungan Hidup Nomor 4 Tahun 2001 tentang Kriteria Baku Kerusakan Terumbu Karang.

Lalamentik, L.T.X., Sompie, D., Runtukahu, F., Kojansow, J., dan Rondonuwu, A.B. 2013. Coral Bleaching in Ratatotok Peninsula and its surrounding area, South-east Minahasa, North Sulawesi Province, Indonesia (a 15 years monitoring data). J. Marine Sci. Res. Dev. 3:3. 
Manuputty, A.E.W. 1990. Sebaran, keanekaragaman dan komposisi karang batu di perairan Kabil. Pusat Penelitian dan Pengembangan Oseanografi-LIPI. Jakarta: 15-23.

Mellawati, J., Susiati, H., SBS, Y. 2012. Pemetaan Awal Terumbu Karang Di Ekosistem Pantai Sekitar Calon Tapak Pltn Bangka Selatan. Prosiding Seminar Nasional Pengembangan Energi Nuklir V, Pusat Pegembangan Energi Nuklir. Badan Tenaga Nuklir Nasional, Jakarta.

Nybakken, J.W. 1992. Biologi Laut. Jakarta: PT Gramedia Pustaka Utama.

Papu, A. 2011. Kondisi Tutupan Karang Pulau Kapoposang, Kabupaten Pangkajene Kepulauan, Provinsi Sulawesi Selatan. Jurnal IImiah Sains. 1 (11) : 6-12.

Pontoh, O. 2011. Penangkapan Ikan dengan Bom Di Daerah Terumbu Karang Desa Arakan Dan Wawontulap. Jurnal Perikanan dan Kelautan Tropis. VII (1): 56-59.

Rembet, U.N.W.J., Boer, W., Bengen, D. G., Fahrudin, A. 2011. Struktur Komunitas Ikan Target Di Terumbu Karang Pulau Hogow dan Putus-Putus Sulawesi Utara. Jurnal Perikanan dan Kelautan Tropis. VII (2): 60-65.

Kramer, P.J. 1980. Plant and Soil-Water Relationship. McGraw-Hill Book Company, Inc. New York.

Lenak, A.A. 2014. Penggulungan Daun dan Alokasi Biomassa pada Padi Lokal Sulut saat Kekurangan Air [Skripsi]. FMIPA Universitas Sam Ratulangi. Manado.

Lestari, E.G. 2006. Hubungan antara Kerapatan Stomata dengan Ketahanan Kekeringan pada Somaklon Padi Gajahmungkur, Towuti, dan IR 64. Biodiversitas. 7(1):44-48.

Maynard, G.H dan D.M Orcott. 1987. The Physiology of Plants under Stress. John Willey and Sons, Inc. New York.

Nio, S.A., A.H Siregar dan S.N Widyanto. 1997. Aktivitas Peroksidase pada Lini Kalus Padi
(Oryza sativa L.) Toleran Kekeringan. Eugenia XIII. 3(3):102-108.

Nio, S.A dan Y. Banyo. 2011. Konsentrasi Klorofil Daun sebagai Indikator Kekurangan Air pada Tanaman. Jurnal IImiah Sains. 2(2):165-173.

Nio, S.A dan D.P.M Ludong. 2013. Comparing the Drought Tolerance of Local Rice Cultivar Superwin with Other Cultivars Cultivated in North Sulawesi Province Based on Dry Matter Partitioning. $4^{\text {th }}$ International Converence of Global Resource Conservation. Brawijaya University

Nio, S.A dan Y. Banyo. 2011. Konsentrasi Klorofil Daun sebagai Indikator Kekurangan Air pada Tanaman. Jurnal IImiah Sains. 2(2):165-173.

Noogle, G.R dan G.J Fritz. 1983. Introductory Plant Physiology. Prentice Hall, Inc. New Jersey.

Prihastanti, E. 2010. Kandungan Klorofil dan Pertumbuhan Semai Kakao (Theobroma cacao L.) pada Perlakuan Kekurangan Air yang Berbeda. BIOMA. 12(2): 35-39.

Prihastanti, E. 2011. Specific Leaf Area, Jumlah Trikomata dan Kandungan Kalium Daun Semai Kakao (Theobroma cacao L.) pada Kandungan Air Tanah Berbeda. BIOMA. 13(2):85-90.

Purwanto dan T. Agustiono. 2010. Kajian Fisiologi Tanaman Kedelai pada Berbagai Kepadatan Gulma Teki dalam Kondisi Cekaman Kekeringan. Jurnal Agroland. 17(2):85-90.

Sarwar, M.J dan Y.M Kanif. 2005. Low Water Rice Production and Its Effect on Redox Potential and Soil pH. Agron. J. 4:142-146.

Sasmitamihardja, D. dan A. Siregar. 1996. Fisiologi Tumbuhan. Depdiknas. Jakarta.

Sutoro, I. dan Samadiredja. 1989. Reaksi Pemuliaan Tanaman Jagung dan Sorghum pada Fase Pertumbuhan Vegetatif. Penelitian Palawija. 9(4):146-151.

Torey, P. 2013. Karakter Morfologi Akar sebagai Indikator Kekurangan Air pada Padi Varietas Superwin [Skripsi]. FMIPA Universitas Sam Ratulangi. Manado. 